\title{
La identidad reelaborada en Galíndez de Manuel Vázquez Montalbán
}

\author{
SANTIAGO SEVILLA-VALLEJO
}

Muriel Colbert trata de aclarar la desaparición de Jesús de Galíndez, un político crítico con el régimen de Trujillo y defensor de los derechos del pueblo vasco, que, treinta y dos años después de su desaparición, ha sido olvidado. En ese momento, Muriel Colbert entrevista a las personas que lo conocieron, estudia documentos sobre él y visita las ciudades en las que estuvo. Galíndez es una obra que reflexiona sobre el carácter discursivo de la historia y de la identidad. Ambas son reelaboradas constantemente de acuerdo con las interpretaciones que hacen los personajes de los hechos. En esta novela, el punto de vista de la ética de la resistencia que representan Jesús de Galíndez y Muriel Colbert da coherencia a la compleja y contradictoria red de datos e interpretaciones. Asimismo, estos dos personajes adquieren una identidad propia en su lucha por mantener viva la ética de la resistencia en un mundo que tiende a olvidar el pasado y dejarse llevar por la manipulación. La propia Muriel considera que Galíndez representa la ética de la resistencia y, en el presente artículo, este concepto se entiende en el sentido de que trata de emanciparse de los poderes dominantes y ayudar a otros a que sigan su ejemplo, aunque, en último término no consigue esto sino únicamente oposición o resistencia frente a esos poderes (Habermas), como una actitud necesaria en todas las sociedades.

La búsqueda de la identidad es un ámbito que preocupa en nuestra sociedad. Cada ser humano es consciente de que debe dar respuesta a qué le define cómo distinto de otras personas y a cómo se relaciona con los demás. Debe llegar a conformar unos sentimientos, pensamientos y acciones propios que le individualicen y le socialicen al mismo tiempo. Uno de los instrumentos o, en los términos de Jesús G. Maestro, una tecnología especialmente propicia para definir nuestra identidad es el lenguaje. Según Paul Ricoeur, el sujeto mediante el discurso "se construye a sí mismo y, a la vez, construye un mundo como objeto. Su paradójico estatus es pues el de ser a la vez productor y producto de su discurso" (Roca 14). La identidad del ser humano es una combinación entre la realidad, que se refiere a los hechos que vive, y la ficción, que tiene que ver con aquel relato que construye en base a su imaginación. 
Ricoeur "demuestra cómo el tiempo humano se constituye en la intersección, o percepción conjunta del tiempo histórico (cosmológico) y el tiempo de la ficción, abierto ilimitadamente" (Roca 53). La narración que hacemos de los acontecimientos configura la percepción que tenemos de nosotros mismos, las relaciones que establecemos con los demás y la comprensión que tenemos del mundo: "narrating enables speakers/writers to disassociate the speaking/writing self, and thereby take a reflective position vis-a-vis the self as character in past or fictitious time-space, make those past (or imagined) events relevant for the act of telling (a bodily activity in the here-and-now)" (Bamberg 5).

El modo con que empleamos el lenguaje nos otorga una determinada identidad, por lo que la identidad es constantemente construida a través del discurso. En este sentido, podemos hablar de una "identidad discursiva" y de una "identidad en práctica" para referirnos al proceso lingüístico que forma nuestra personalidad (Kanno y Stuart 238). Galíndez cuenta la investigación que hace Muriel Colbert sobre la desaparición de Jesús de Galíndez en la que reelabora la identidad de este personaje porque, como ocurre con cualquier identidad, es fruto de la combinación de hechos objetivos e impresiones subjetivas. Muriel entra en contacto con diversas personas que lo conocieron y entre todos generan un complejo y contradictorio retrato del político y escritor vasco. En esta novela se refleja la construcción de esa identidad que es una ficción cultural fruto del empleo del lenguaje (Sevilla-Vallejo 2017b 291). Muriel Colbert pretende recuperar los últimos momentos de aquel a quien considera su héroe, pero los testimonios que recibe, tanto en entrevistas como en documentos, están constantemente transformando la imagen que tenía hasta el momento de él. Asimismo, la investigación acerca de Galíndez afecta a la identidad de la investigadora y del resto de personas que entran en contacto con el político vasco. La complejidad y contradicción de Galíndez reflejan la misma situación política en la que vivió y el choque entre los deseos y la realidad de cada uno de los personajes. Galíndez nos invita a una reflexión crítica que no se conforma con el relato que viene dado por los agentes de poder que lo han construido (Bodenmüller 75). Del mismo modo, se pone de relieve que la identidad no es un punto de llegada, sino la motivación para estar permanentemente construyendo los rasgos que nos definen en diálogo con la sociedad en la que vivimos y con la sociedad que nos recordará después de que hayamos muerto.

Manuel Vázquez Montalbán (MVM) fue un autor comprometido con la sociedad porque consideraba que el escritor debía dar claves políticas que ayudaran a llegar a un verdadero diálogo entre los ciudadanos para 
construir una sociedad más justa. MVM fue pionero en la novela de investigación, que se caracteriza por hacer hincapié en "que no se trata tanto de investigar los mismos hechos como de cuestionar los discursos sobre la realidad" (Champeau et al. 17). MVM nos da claves para entender lo que está pasando en la sociedad española porque la situación respecto de la memoria histórica ha cambiado poco desde que él escribiera. Vivimos la curiosa paradoja de que disponemos de instituciones que defienden la democracia como el sistema que establece la participación ciudadana y, al mismo tiempo, tenemos la conciencia de que los mecanismos políticos que nos dirigen responden escasamente a una verdadera democracia. No es necesario dar ejemplos concretos de corrupción o incertidumbre política para comprender la encrucijada en la que vivimos. MVM no se dejó vencer por la falsa apariencia de democracia, sino que nos instó a seguir luchando cada día por una sociedad más crítica. En este sentido, consideraba que uno de sus objetivos era "cargar de contenido, de un nuevo sentido, al sistema democrático" ( $a$ pud Tyras 195).

Galíndez es una de las muchas novelas en las que este autor reflexiona acerca de los mecanismos por los que el poder político manipula la historia de la humanidad. MVM llevó a cabo un retrato de la sociedad contemporánea que nos sirve para darnos cuenta de la necesidad de oponer una resistencia a las numerosas manipulaciones que vivimos en el día a día. En la actualidad, la clase política ejerce un control sobre la población más poderoso que en épocas anteriores. En nuestro sistema político, el ciudadano entrega con su voto "un cheque casi en blanco", mientras que los partidos políticos "ideologizan, programan, prometen, gestionan y oponen” (Vázquez Montalbán 1995 13). Panfleto desde el planeta de los simios comienza señalando que el poder actualmente se apoya en cuatro saberes "complejos y complementarios: el económico, el legislativo-administrativo, el propagandístico y el organizativo" (13). El poder político influye en la forma de distribuir los bienes, regla nuestro comportamiento, afecta a nuestra forma de pensar y establece el funcionamiento social por el que nos regimos. Para afrontar las posibles manipulaciones que se dan en cualquier sociedad, los individuos deben mantener viva la ética de la resistencia. En Galíndez, tenemos dos personajes que representan esta visión: Jesús de Galíndez, que muere en sospechosas circunstancias políticas, y Muriel Colbert, que investiga ese hecho, lo cual la conduce también a la muerte.

En Panfleto desde el planeta de los simios, MVM también ofrece un interesante análisis del papel de los intelectuales en la sociedad. Según 
él, son aquellas personas con saberes específicos que reflexionan y toman una postura sobre cómo debe ser la organización del grupo en el que viven y son capaces de transmitir esa postura (1995 33 ss.). Aunque el pensamiento de cada uno de estos individuos puede diferir del resto, los intelectuales se agrupan en dos conjuntos: aquellos que reproducen las ideas del poder y aquellos que las cuestionan. La oposición entre ambos grupos cumple "una relación dialéctica fundamental para que la historia exista" (1995 35). El escritor, el investigador y el resto de los intelectuales tienen la función fundamental de mantener una distancia crítica que les permita valorar la organización social y denunciar las manipulaciones e injusticias que se puedan dar. No obstante, "cada nueva hornada de intelectuales críticos tiende a cansarse de tanta tensión y acaba buscando coartadas para legitimar 'lo obtenido' y el poder de que lo representa como si fuera o inevitable" (1995 37).

En el mencionado ensayo, MVM explica cómo la sociedad occidental dejó de tener la religión como objeto fe, en cuanto que criterio incuestionable, a finales del siglo XIX (1995 67 pp.). El objeto de fe fue reemplazado por el progreso a comienzos del siglo XX, pero, después de la sucesión de las guerras mundiales y de infinidad de guerras menores y del injusto reparto de la riqueza, ha dejado de resultar creíble. La humanidad contemporánea lleva una tendencia a la falta de referentes de sentido, lo cual deja al ser humano abandonado en una realidad que no puede explicar de acuerdo a un fin determinado y esto genera un malestar social en el que el poder político adquiere una gran capacidad de manipular a la población. Según MVM, en el caso de España, a esta falta de referentes se añade que, con el fin de superar la dictadura, la transición democrática inició una situación de presentismo, por la que se deja de lado la memoria histórica. De este modo, el sujeto queda en mitad de un desierto, sin referentes de dónde viene ni cuál debe ser su destino. El poder actual no trata exactamente de controlar el pasado para controlar el futuro al estilo orwelliano, sino de eliminar el pasado (y de paso el futuro) para que quede un indeterminado presente. Esta situación es problemática por muchos motivos y su abordaje holístico supera la brevedad de este estudio. Para un tratamiento amplio del tema, se puede consultar el estudio de Mari Paz Balibrea y el testimonio del autor recogido por Georges Tyras. En nuestro caso, nos limitaremos a lo que afecta a la identidad. El discurso político que alimenta el presentismo pone al individuo en una situación de lo más complicada porque su identidad, lo que constituye la base de su forma de pensar, sentir y actuar, queda muy desdibujada sin la memoria del pasado. Así, Galíndez y Muriel se ven 
abocados a una lucha constante de recuperación y construcción de sus identidades.

\section{La necesidad de lo histórico en la ficción}

Tal como dialogan MVM y Georges Tyras, Galíndez es una novela que reacciona frente al ahistoricismo generalizado de la novelística española de la transición y los comienzos de la democracia española. MVM se propuso en Galíndez "alcanzar un nivel en el que lo real pueda parecer ficción y la ficción pueda parecer real" (Navarro 1990). Muriel Colbert se identifica con la lucha solitaria y mal comprendida de Jesús de Galíndez. Cumple la función de recuperar la memoria del político vasco que da nombre a la novela. Una de sus motivaciones es que se siente "carente de sentido histórico porque pertenece a un país que se ha apoderado de la Historia y no quiere ser consciente de ese secuestro" y, gracias al ejemplo de Galíndez, encuentra que su objetivo es recuperar la memoria histórica. De manera que "Muriel Colbert es evidentemente un personaje instrumentalizado, pero llega un momento en que se vuelve autónomo" (Tyras 139), cuando hace propia la lucha de Galíndez y decide llevarla hasta el final.

Involucradas mutuamente, la historia verdadera del exiliado vasco y la historia ficticia de la investigadora norteamericana remiten una a otra, borrando en la oscilación muchos rasgos característicos del "original" y de la "copia" Entre el discurso referencial y el discurso mimético no hay solución de continuidad: ambas formas se funden en una incertidumbre indiferenciada (Pittarello 743).

Galíndez fascina a MVM porque lucha contra distintos poderes opresivos, pero no le retrata como un santo, sino con facetas contradictorias que humanizan su lucha, en sus virtudes y en sus defectos. Galíndez es un representante del PNV que se exilia durante la dictadura en la República Dominicana. Desde su exilio, critica los abusos que lleva a cabo Trujillo en su tesis La era Trujillo. Por lo que el gobierno de la República Dominicana le pide que no publique su tesis, pero él sigue adelante y el gobierno dominicano, con el apoyo del estadounidense, lo secuestra y asesina. Por su parte, Muriel trata de aclarar la muerte de Galíndez, su tutor de tesis la insta a cambiar de tema y otros también tratan de que abandone el asunto, ella persiste y es secuestrada por los mismos gobiernos que Galíndez. A medida que avanza la novela, las identidades de Galíndez y de Muriel se aproximan, hasta que acaban por 
ser, en cierta medida, la misma. Si bien son personajes distintos en detalles biográficos (sexo, edad, nacionalidad...), les mueve la ética de resistir frente al poder político. Ambos son verdaderos intelectuales que se sacrifican por la verdad.

Aunque Galíndez no hace demasiadas referencias a la situación española, es un relato que invita a reflexionar sobre la opresión de la dictadura española y el presentismo de la democracia. En palabras de Mari Paz Balibrea, retrata "el discurso de una España por fin libre del yugo fascista y de su atraso secular -y por eso nueva- fue poco a poco tomando la forma de una obsesión que insistía hasta el absurdo en una España joven y nueva, que nacía a la historia con la democracia y que estigmatizaba cualquier intento de ser relacionada con el pasado anterior a 1975" (112). La obra de MVM nos ayuda a comprender la compleja situación en la que surge la democracia en España. Tras la muerte de Franco, fue preciso llevar a cabo un acercamiento entre las diversas posturas políticas, pero no podemos conformarnos con la imagen que hemos recibido de este momento decisivo, sino que debemos reflexionar acerca de los mecanismos de poder que dieron lugar a este proceso. "El olvido histórico que se establece en la España democrática es particularmente radical porque, encima de servir los intereses de los grupos con poder político y económico, se asienta además sobre las premisas de la política de reconciliación que los grupos antifranquistas -encabezados por el PCEhabían apoyado durante el tardofranquismo" (Balibrea 115). Las novelas de MVM recuperan el pasado para que los lectores puedan reflexionar acerca de su identidad colectiva. "MVM recupera historias del olvido, no como nostalgias de un pasado que no ha de volver, sino como orígenes extraviados de un presente que no se puede entender, ni criticar, ni transformar, sin ellos" (Balibrea 122). De este modo, "[1]a lectura acerca del pasado histórico convierte al lector en sujeto histórico, es decir, comprende su identidad en un determinado momento como producto de una serie de acontecimientos pasados" (Balibrea 122).

Asimismo, Galíndez es una de las novelas de MVM que nos enfrenta a la constatación de que la historia es un proceso discursivo, es decir, los hechos que le acontecen al ser humano son transito-rios y lo que recordamos de los mismos y cómo nos entendemos a nosotros mismos en relación con ellos son fruto del relato que construimos. En el caso de la novela que nos ocupa, si bien es cierto que existió un activista vasco llamado Jesús de Galíndez, que escribió La era Trujillo y desapareció; la imagen que formemos de este como agente histórico o como ser humano es fruto de una narración. Mari Paz Balibrea amplía este proceso de 
construcción de la identidad del protagonista estudiando la relación entre el texto y la posmodernidad. En nuestro caso, vamos a centrarnos en la construcción textual de Galíndez.

Se puede especular sobre este hombre a través de los documentos o se puede pedir el punto de vista a quienes lo conocieron, pero siempre se trata de una reconstrucción o, como dice José Colmeiro, de una reescritura. Vázquez Montalbán, Muriel y el lector reelaboran a Galíndez y, al mismo tiempo, se reelaboran a sí mismos. En esta novela, el desarrollo discursivo va acompañado de un marco histórico con fechas de hechos reales y ficticios (anexo 1). Como se verá, esa combinación de hechos verdaderos y hechos o noticias falsos nos señala que los datos son tan manipulables como cualquier otra parte del discurso y que, por lo tanto, la memoria en torno a la que se construye la identidad humana es artificial en gran medida. En el anexo 2, se ofrece una organización de los hechos relatados en cuatro periodos: Primeros años de Galíndez, Orígenes del conflicto, La desaparición de Galíndez y El fantasma de Galíndez regresa.

Los hechos aparecen con fechas exactas, en lugares reales concretos y con una minuciosidad que sugiere que son históricos; pero hay casos en que el hecho es inventado y no hay ninguna marca textual que permita diferenciarlo de un hecho real. Por ejemplo, don Angelito piensa lo siguiente. "Quizá debería fingir una precisión basada en el dato [...] Anote esta fecha: cuatro de marzo de mil novecientos cuarenta y uno. Galíndez me confiesa que pasa información a la embajada americana. ¿Lugar? Un café de la calle Colón. ¿Hora? Las siete en punto de la tarde" (321). Desde el momento en que el lenguaje cuestiona la verdad de los hechos, el lector no sabe nunca qué acontecimientos tomar por ocurridos y cuáles son una pura invención de un personaje (Sevilla-Vallejo 2017a 33). En Galíndez, los propios personajes inventan los datos, de modo que es imposible saber a ciencia cierta si lo que dicen es verdad o no y, por tanto, el lector no puede descartar muchos de los hechos y tampoco puede llegar a una conclusión segura sobre lo que sucedió. La novela plantea el problema sin solución de que el pasado es constantemente reelaborado según los puntos de vista de quienes participan en su recuperación, por lo que no es posible quedarse con la versión que recibimos porque entonces nos vemos afectados por manipulaciones. Esto es tan radical que ni siquiera Muriel Colbert, que no busca ningún lucro ni reconocimiento con su investigación, es objetiva. Solo a través de la perspectiva de $\mathrm{Mu}$ riel Colbert "recuperamos el pasado, en el entendimiento de que es "su" versión lo que se nos relata" (Balibrea 165). No obstante, Muriel Colbert 
nos ofrece un valor importante: buscar por uno mismo la verdad del pasado. El ciudadano crítico y que quiera construir una identidad propia y contribuir a la identidad de su comunidad debe ser consciente de que ninguna sociedad es necesariamente como muestra la versión oficial y, por lo tanto, debe cuestionarla y reelaborarla constantemente.

En Galíndez hay una serie de grupos que ejercen poder en diferentes direcciones (Pittarello 745). En cada uno de los países en los que transcurre la novela hay grupos opuestos. En España, franquistas frente a independentistas vascos; y en la República Dominicana, trujillistas frente a antitrujillistas. Los opuestos de Estados Unidos son más ambiguos, aunque existen. Los organismos gubernamentales colaboran o transigen las actividades trujillistas; en cambio, hay casos como el senador Charles O. Porter o el perió-dico Time que tratan de resolver la desaparición de Galíndez. Cada uno de los grupos tiene su manera de entender la desaparición de Galíndez. Para comprender lo que sucedió podemos remitirnos a Rashomon, sobre la que Muriel dice lo siguiente: "En la película se cuenta un mismo hecho mediante distintas apreciaciones de diferentes testigos y el espectador ha de hacer el esfuerzo de elegir una de las versiones o ir reuniendo elementos de una y de otra" (105). MVM dice lo siguiente sobre Galíndez: en ella "expreso la necesidad de luchar contra el sistema y de sospechar del poder como declaración de principios" (Tyras 171). El lector debe construir su propia percepción del mundo y mantener un sentido crítico que le permita evitar y contrarrestar las manipulaciones. Esto tiene un fondo que va más allá de cualquier sociedad concreta hasta adquirir un valor antropológico, porque en toda sociedad hay "estructuras de poder interesadas -en el presente- en producir y mantener una cierta verdad histórica, y resueltos a silenciar todo lo que no encaje en ella" (Balibrea 172).

Jesús de Galíndez no es tan importante por su pensamiento, sus escritos o sus acciones personales, como por ser el símbolo del individuo que se resiste a conformar su identidad bajo el molde de ningún sistema político y es su rechazo del relato dominante lo que hace que los poderosos le teman y acaben con él. La investigación sobre él que lleva a cabo Muriel Colbert tiene un aspecto ético fundamental. No importan tanto los hechos objetivos de la biografía de Galíndez como determinar que su lucha fue valiosa pese a la aparente derrota. "Montalbán levanta un especio narrativo en el que la memoria es el eje básico" (Bértolo 69). Galíndez trata de dar a conocer la verdad de Trujillo y Muriel la de Galíndez, pero no es posible "saber toda la verdad sobre el caso Galíndez", sino solo "una verdad" (29). Galíndez fracasa en su proyecto de 
conseguir la libertad del pueblo vasco y, una vez le secuestran, solo le queda mantener entereza frente a la muerte. "Has de prepararte para dar cara tu muerte, para que tu gesto refleje la responsabilidad de tu muerte, para que se enfrenten a la dignidad de tu muerte" (179). Sin embargo, Galíndez tiene una conciencia histórica y, hasta el último momento, quiere que su imagen perdure: "...has de decir algo importante, algo que no olviden, que te haga en su memoria vencedor de la muerte" (270). Parecería que Galíndez fracasa en el intento de recuperar la memoria histórica y de instalarse en ella porque el poder represivo consigue hacerle desaparecer. Nadie conoce los sufrimientos que pasa Galíndez en una prisión de la República Dominicana. De modo que su heroicidad frente a la muerte parece que no afecta a la historia. Este aparente fracaso comienza mucho antes de que sea apresado. Galíndez trata de forjarse una imagen de luchador vasco, pero es ignorado por sus paisanos y trata de denunciar al régimen de Trujillo, pero es silenciado. El único efecto que tiene sobre la sociedad es que se convierte en objeto de una disputa internacional, que se extiende durante más de treinta años sin ninguna consecuencia. Muriel Colbert es la única que se preocupa de Galíndez personalmente y va tras sus huellas. En el anexo 2 se transcriben los datos más importantes para comprender por qué desapareció Galíndez, qué efectos tuvo su desaparición y qué generó la investigación de $\mathrm{Mu}$ riel.

Pese a todo lo dicho, Galíndez muestra que la manipulación de la historia no puede ser total. Siempre que se mantenga viva la llama de la ética de la resistencia, no vencerán del todo los que tergiversan la historia por sus propios intereses porque seguirá adelante la dialéctica entre el poder y la denuncia y oposición al mismo. Galíndez es juzgado por vascos, exiliados españoles, dominicanos (durante su tortura y después), agentes de Estados Unidos y Muriel Colbert. Los datos recogidos en el anexo "Orígenes del conflicto" señalan los motivos por los que se enemistó con la República Dominicana y los compromisos que adquirió con Estados Unidos. En "La desaparición de Galíndez", podemos ver cómo distintos grupos dominicanos y estadounidenses le juzgan moralmente y su desaparición genera reacciones. Trujillo hace asesinar a muchos de los implicados en el secuestro, lo que provoca que Estados Unidos le rechace, que pierda apoyos y, a la postre, muera en un atentado. Galíndez funciona como un fantasma. Desaparece del mundo antes de ver los resultados de La era Trujillo, pero su recuerdo se mantiene. Cuando Muriel investiga, "[e]l fantasma de Galíndez regresa", se despierta la polémica que había estado acallada desde que Balaguer borrase las huel- 
las del asesinato en los años sesenta. De este modo, perdura no tanto la memoria concreta sobre Galíndez como la ética de la resistencia en cuanto labor imprescindible para la sociedad.

Escritura de la historia: el poder frente a la ética de la resistencia José Antonio Bonilla, profesor de la Universidad de Santo Domingo, escribió un artículo en el año cuarenta y seis en el que señalaba que el principal problema del gobierno de Trujillo estaba en que toda la autoridad del Estado recaía sobre una sola persona: "No comparto el criterio de que nuestro país sólo cuente con un hombre, el Presidente Trujillo, para regir sus destinos [...] Los Estados Unidos contaba con Roosevelt, éste falleció en difíciles momentos y Truman lo ha sustituido [...] En nuestro país se ha producido un fenómeno durante toda la historia: siempre ha habido un solo hombre" (1). La novela Galíndez presenta una crítica al poder concentrado en una sola persona en el caso de la República Dominicana, que sirve como espejo para pensar también sobre la dictadura de Franco en el caso de España. Ambos países comparten que tuvieron en el siglo XX una larga dictadura que amenazó con borrar muchas de las señas de identidad de sus culturas. La narración se sitúa en un momento en el que en España se había establecido la democracia pero que, de una manera diferente, también olvidó su pasado. En este sentido, MVM sostiene que la ética de la resistencia de Muriel proviene de que esta "penetra en el mundo del recuerdo y puede archivar lo que fue ese pasado" (Tyras 176), es decir, no puede tanto liberarse de los poderes que acabaron con Galíndez, pero si puede perpetuar la memoria del hecho.

Muriel reactiva un proceso dialéctico de escritura. "El caso Galíndez abrió un largo proceso textual, de escritura y reescritura de la historia desde los frentes más opuestos" (Colmeiro 213), tanto en la realidad como en la novela de Vázquez Montalbán. La novela hace referencia a diversos textos. A su muerte, Galíndez deja La era Trujillo, una tesis que reescribe la Historia contemporánea de la República Dominicana. Este texto genera muchas reacciones. La verdad sobre la era de Trujillo, Refutación de "La era" de Galíndez de Antonio Bonet rebate las afirmaciones hechas por Galíndez. De este modo, reescribe la historia que ha reescrito Galíndez. Por otra parte, aparecen en Estados Unidos informes opuestos. Mientras Charles O. Porter denuncia el asesinato del piloto del avión en que Galíndez fue secuestrado; Morris Ernst en Report and $O$ pinión in the matter of Galíndez defiende que no ha habido secuestro. En palabras de Robert Robards, "todo lo que Porter había puesto en blanco, 
Ernst lo puso en negro" (127). Asimismo, Muriel Colbert justifica la actualidad de su trabajo con otro libro escrito sobre el mismo tema, $E l$ caso Galíndez: Los vascos en los servicios de inteligencia de EE. UU. de Manuel de Dios Unanué. La imagen que nos queda de Galíndez se escribe con una oposición de posturas, en las que la verdad y los intereses se mezclan.

La obra de MVM se construye sobre testimonios de diversa procedencia, tanto entrevistas como escritos en documentos. Sin embargo, no todos los testimonios sobre la desaparición de Galíndez son igual de veraces. En la novela, Galíndez fue secuestrado y asesinado por el gobierno de Trujillo y ni fue comunista ni fue a ninguna parte después del doce de marzo de mil novecientos cincuenta y seis. Esto lo sabemos porque se narran las torturas a las que le someten los esbirros de Trujillo y las acciones de Galíndez parecen indicar que era enemigo del comunismo. Hay otros datos que no son tan seguros, pero parecen plausibles porque así los percibe Muriel Colbert. Si bien son muchos los personajes que defienden sus opiniones y, por tanto, influyen en la percepción que el lector tiene de la historia; Muriel, como protagonista, tiene más peso sobre la narración. Lo que ella defiende no tiene por qué ser cierto, pero sus opiniones condicionan el valor que adquieren los hechos.

Muriel va al Ministerio de Exteriores a consultar la documentación archivada y, a través de ella, revive la polémica que suscitó la desaparición de Galíndez. La desaparición del político vasco produce un aluvión de escritos: "Y de pronto las carpetas se hinchan y asistes a un doble relato: el dramático, incluso sensacionalista, de los recortes de prensa y las cartas profilácticas de casi todos los embajadores dirigidas al director general de Política Exterior" (201). Corren rumores de que Galíndez ha sido arrojado a las calderas del buque Fundación, pero se demuestra que no es así, amaina la polémica y, a partir de ahí, nadie escribe sobre el tema. Sin embargo, hay informes que indican que Murphy, el piloto que supuestamente se ocupó de transportar a Galíndez en su secuestro, fue asesinado por Trujillo: "Dos años de silencio y rebrota el caso Murphy, de nuevo las carpetas se hinchan, de nuevo el baile verbal de los embajadores..." (205). Es muy interesante el carácter activo que adquieren los documentos. Las carpetas se hinchan y deshinchan indicando la intensidad de la polémica en cada momento como si tuvieran vida.

Muriel aparentemente asiste pasiva a los dictados de los documentos, pero tiene su opinión al respecto. Emite juicios sobre las intenciones de los autores de los documentos: “...las aparentemente bien intencionadas informaciones del Diario de Nueva York en lengua castellana dirigido 
por Ross, el que [...] desorientó más que orientó cuando puso a la opinión pública en las falsas pistas de un Galíndez secuestrado y transportado por mar" (201-202). En un sentido amplio, deja entender que tiene datos concluyentes sobre las torcidas intenciones de Ross. Muriel da claves al lector acerca de cómo entender los testimonios sobre Galíndez. Ella es capaz de leer entre líneas aquello que los diplomáticos saben mas no pueden escribir en sus informes. Por ejemplo, cuando Ferry del Val informa con "profilaxis diplomática", ella ve la "barbarie trujillista" (203). No obstante, si bien Muriel trata de ceñirse a las evidencias objetivas, tiene una implicación emocional con Galíndez que hace evidente su subjetividad. Así, se enfada cuando lee documentos que critican a Galíndez: "Una investigadora no puede indignarse, no puede cerrar la carpeta como tú la has cerrado, ni abrirla con esa sensación de vergüenza profesional" (205); y, cuando lee el modo en el que fue asesinado, su identificación llega hasta lo corporal: "te duele el cuello, te duele el cuerpo de Galíndez bajo las paletadas de arena" (206). Esto hace muy difícil que su investigación sea objetiva. Del mismo modo, resulta intrigante el conocimiento tan preciso que tiene Muriel sobre los hechos. Es llamativo que conoce detalles privados de los implicados en el secuestro. El gobierno de Trujillo defiende que De la Maza se suicidó, mientras que otros testimonios sostienen que fue asesinado. El gobierno de Trujillo pide a Rúa, suegro de De la Maza, que acepte el suicidio. Muriel dice que Rúa promete hacerlo después de ver los procedimientos que emplea el gobierno de Trujillo y lo hace "causándose a sí mismo y a su conciencia una gran violencia" (212). Para que Muriel sepa los motivos que llevan a actuar a Rúa y sus reacciones interiores, tendría que habérselas confesado él o alguien cercano. No se sabe a ciencia cierta cómo conoce estos datos, pero es claro que tiene más conocimientos sobre el caso Galíndez y los hechos que lo rodean que el resto de los personajes. Muriel canaliza las informaciones acerca del caso Galíndez, les da una lógica, pero no se ha de olvidar que lo hace desde su punto de vista y que sus intervenciones no son objetivas.

Galíndez trata la historia como si fuese un texto que están escribiendo sin interrupción múltiples autores. "La yuxtaposición textual de distintas versiones de la historia reproduce el proceso selectivo de construcción de la historia, revelando la participación en ella de múltiples agentes institucionales desde los poderes fácticos hasta los anónimos poderes ocultos" (Colmeiro 6). Robert Robards le dice a don Angelito que tienen la misión de ocultar la verdad sobre la muerte de Galíndez de la siguiente manera: “¿No abrimos cada mañana una página en blanco y sólo 
tenemos veinticuatro horas para escribirla?" (239). Ellos no son escritores, sino agentes que trabajan para los Estados Unidos, pero sus acciones escriben parcialmente la historia. El servicio de inteligencia de Estados Unidos trata de ocultar la memoria histórica del caso Galíndez, pero Muriel está dispuesta a recuperarla. El poder político de este país cuenta con la mayor parte de los medios y ella, como investigadora, solo dispone de la ética de la resistencia, como si se repitiera el combate de Goliat y David. Por ello, Robert Robards se jacta de que Estados Unidos tiene poca historia, pero la escribe conforme a sus intereses. El problema es que, para sostener esa historia, aquellos que representan a Estados Unidos deben borrar los hechos históricos que no encajan con esa narrativa. El control que tienen es limitado porque se ven obligados a vigilar por si alguien pretende reavivar el recuerdo de hechos que ya ocultaron, como es el caso Galíndez. La investigación de Muriel es una amenaza a la historia que han escrito, se trata de "un cambio en la memoria oficial, la del poder hegemónico, supone no sólo el cuestionamiento del pasado, sino una brecha en una historia que el poder desea construir monolítica, una posibilidad de cambio, de construcción de nuevas historias/realidades, la transformación de una estructura hermética en una abierta" (Magariños 4). La vía de la esperanza frente a la manipulación política reside en que, mientras haya personas implicadas en la ética de la resistencia, la verdad no puede ser acallada. Aunque la colaboración entre agentes de Estados Unidos y el gobierno de Trujillo consigue hacer desaparecer la mayor parte de las evidencias respecto de Galíndez, Muriel es capaz de recuperar los rescoldos que quedan de la memoria del caso Galíndez y, cuando ella también muere a manos de los torturadores, consigue que vuelva a haber un verdadero caso abierto con evidencias de manipulación política. "Muriel constituye con su muerte lo que Galíndez no pudo con la suya: un cadáver" (Balibrea 175).

La identidad en la práctica de Jesús de Galíndez y Muriel Colbert Galíndez tiene rasgos de novela negra e histórica, pero, en contra de lo que suele pasar en estas, no apunta "a una verdad" (Pittarello 742). Se caracteriza por su "escepticismo respecto a la posibilidad de adquirir un conocimiento objetivo y universal sobre el mundo que nos rodea" (Benson 235) o, dicho de otra manera, el conocimiento del mundo es subjetivo y múltiple. La historia es fruto del conjunto de testimonios que la forman, los cuales responden a diversos intereses y perspectivas $\mathrm{y}$, a veces, son contradictorios entre sí. Galíndez es un texto polifónico, en el que "[e]l juego narrativo se va ensamblando a partir de estos discursos 
que el autor va interrumpiendo y retomando estratégicamente, para dar la apariencia de una ausencia de dirección narrativa" (Navarro 1990 octubre 40). MVM emplea "diversas voces, de varia condición ideológica y moral" (Valls 112) para recoger en su historia toda la complejidad del caso Galíndez y construir así una narración polifónica.

Pese a la diversidad de opiniones entre los personajes, la coherencia narrativa proviene de Galíndez y Muriel porque representan la ética de la resistencia. Estos personajes no persiguen un beneficio propio, sino la denuncia del abuso de poder. Sus pensamientos son narrados mediante un monólogo en segunda persona (García Posada), que les "otorga [...] el privilegio de su perspectiva sobre la realidad [...] les concede el privilegio de la íntima distancia de sí mismos" (Balibrea 172). Es decir, ellos tienen un mayor grado de reflexión sobre lo que ocurre. Desde el comienzo de la obra, Muriel está estrechamente unida a Galíndez: “"En la colina me espera... en la colina me espera...'. 'El verso te da vueltas por la cabeza, como si fuera un surco rayado de un viejo disco de piedra. 'Y volveré... volveré o me llevarán ya muerto... a refundirme en la tierra...'. $\mathrm{Ni}$ siquiera eso fue posible, Jesús, musitas y te parece hablar con ese extraño compañero enquistado que desde años llevas dentro de ti'" (11). Muriel se siente identificada con Galíndez, por lo que lleva a cabo una búsqueda, que es tanto sobre el secuestro de Galíndez, como un intento por encontrar su sitio en el mundo. Muriel al principio carece de una identidad definida. Sabemos que, a raíz de una relación sexual, su familia la rechazó por escrúpulos morales y que ha tenido dos novios, uno chileno y otro español. Muriel es una mujer que carece de raíces históricas y familiares y que se empareja con hombres que representan la falta de memoria histórica producida por las dictaduras de sus respectivos países. La vida de Muriel se define por una falta de identidad, hasta que empieza la investigación sobre Galíndez. Mientras investiga en el Ministerio, le vienen a la mente sus problemas personales: "En cinco centímetros de mapa el consultorio del padre de Galíndez, el Ministerio donde Galíndez descansa en la paz de las carpetas y la casa de Ricardo (el novio de Muriel) en la plaza Mayor..." (216). Muriel reelabora tanto la identidad de Galíndez como elabora la suya propia. Ella encuentra sentido a su vida y construye primero una identidad discursiva con lo que lee sobre y escribe sobre Galíndez, pero su tesis no es meramente un ejercicio intelectual, sino una postura ante el mundo, que acaba por constituir su identidad en práctica, que la lleva a sentir, pensar y actuar como Galíndez o, en otras palabras, conforme a la ética de la resistencia. Ambos personajes se engrandecen a los ojos del lector por la consciencia 
que tienen de que luchan por una causa necesaria para la humanidad, aunque eso les suponga la muerte. Ellos se transforman en héroes que luchan en una batalla incierta por la memoria histórica. Cuando Galíndez comprende que la muerte está cerca, se dice a sí mismo lo siguiente: "Preferible que le pidas unos versos prestados a Villon o que te des prisa en recordar, porque hasta la memoria va a quitarte" (269). El empleo de la segunda persona, confunde los discursos del narrador con los de Galíndez y Muriel. Se produce una "situación alocutiva en la cual el tú apostrofado (Muriel Colbert y Jesús de Galíndez) supone un yo locutor sin identidad fija" (Pittarello 746) para que asistamos a cómo un hombre y una mujer normales cargan con el sacrificio, en el que sienten miedo y, al mismo tiempo, encuentran el valor para luchar. Si bien Galíndez está narrado desde múltiples perspectivas, de un modo polifónico, el discurso del narrador se identifica con el de Galíndez y Muriel. Estas tres voces establecen el punto de vista en la ética de la resistencia. Pese a que los agentes estadounidenses y dominicanos acaban con las vidas de Galíndez y Muriel, en la novela no consiguen acallar sus voces. No se puede negar que ambos fueron brutalmente asesinados.

Conviene resaltar que ni Jesús de Galíndez ni Muriel Colbert aparecen como seres idealizados. Ellos tienen sus defectos y sus conflictos personales. Tal como dice Fernando Valls, "[e]l atractivo de Galíndez proviene de su complejidad, sus recovecos" (113), es un profeta impuro, que, por ejemplo, parece un hombre ridículo lleno de ansias de protagonismo a algunos de los exiliados españoles. Muriel es otra profetisa impura, cuyas decisiones llevan la discordia a su familia y al desconcierto de Ricardo, su novio español, cuando ella decide marcharse sola para llevar a cabo su investigación. La fuerza de voluntad con que luchan por mantener la memoria histórica es lo que les lleva a trascender sus limitaciones como seres humanos y a reelaborar sus propias identidades hasta convertirse en mártires de una causa mayor que ellos mismos porque "[u]no no es nada cuando se enfrenta a un poder que puede actuar con absoluta impunidad" (Valls 116) y, al mismo tiempo, uno es la esperanza de una sociedad verdaderamente democrática, en la que el poder tenga que rendir cuentas de lo que lleva a cabo. Ricardo es un joven que trabaja en el Ministerio de Cultura al cual no le interesa nada ni la historia ni la política. Este representa el presentismo que critica MVM de la sociedad española. Cuando Muriel Colbert muere, empieza a investigar cómo ocurrió. "Galíndez-Muriel-Ricardo son eslabones de una cadena por la libertad" (Valls 116). El gran mérito de Muriel consiste en que Ricardo tome conciencia de que es necesario mantener y luchar por la 
memoria histórica. MVM nos manda el mensaje de que debemos reavivar la ética de la resistencia frente a las inevitables manipulaciones del poder.

\section{Conclusión}

Galíndez es una obra que, a través de una trama de novela de investigación, nos invita a reflexionar sobre la manipulación del poder y la necesidad que tiene cualquier sociedad, y en especial la española, de una ética de la resistencia. Muriel Colbert pretende desvelar cómo fueron los últimos momentos de Jesús de Galíndez, pero los testimonios que recibe, tanto en entrevistas como en documentos, conforman una historia compleja y contradictoria. Galíndez muestra cómo la historia y la identidad son textos que están escribiéndose constantemente por muchos autores. La historia de la desaparición de Galíndez se elabora en torno a los hechos que se cuentan y la imagen de Galíndez y de Muriel están sometidas a constantes cambios, pero hay un aspecto que perdura: la ética de la resistencia. Estos personajes representan la lucha de la humanidad por defenderse de las manipulaciones políticas que van a asociadas al poder. Ambos construyen su identidad gracias a que son capaces de "reflexionar de una forma crítica sobre la autenticidad de las informaciones obtenidas" (Bodenmüller 75).

\section{Anexo 1}

Primeros años de Jesús de Galíndez

- 1915 (12 de marzo) Galíndez nace (13)

- Durante la Dictadura de Primo de Rivera (1923-1930) Galíndez recibe su primera ikurriña (177)

- 1929 Nace Ramfis, el hijo de Trujillo (259)

- 1930 (23 de febrero) Trujillo traiciona a Horacio Vásquez y se convierte en presidente interino (248)

Orígenes del conflicto

- Durante la Guerra Civil, Galíndez ayuda a Manuel de Irujo (28) 
- Al acabar la guerra, Galíndez va a Francia y de ahí a la República Dominicana (28)

- 1941 (4 de marzo) Galíndez le confiesa a don Angelito que pasa información a la embajada de Estados Unidos (321). Este dato es inventado por don Angelito, quien después añade que llegó a ser un colaborador fijo en el año cincuenta (363)

- 1941 Galíndez escribe a Martínez Ubago para proponerle ser delegado vasco en República Dominicana (172)

- 1943 Ramfis entra en la Academia Militar (260)

- 1944 Los comunistas y los anarquistas empiezan a salir de la República Dominicana $(28,79)$

- 1945 (17 de diciembre) En La nación aparece un artículo que apoya la huelga (78)

- 1946 Galíndez se traslada a Nueva York (28)

- 1946 Galíndez escribe a Martínez Ubago como delegado vasco en Estados Unidos (175)

- 1946 Huelga azucarera organizada por Báez (75)

- 1948 Don Angelito llega a Miami (143)

- 1950 Galíndez es agente fijo del FBI (363)

La desaparición de Galíndez

- 1953 Galíndez publica en Gernika un artículo sobre el vasquismo (293)

- 1954 Trujillo condena a muerte a Galíndez (127)

- 1954 Diez veces proponen a Ramfis como Jefe de Estado Mayor (260) 
- 1955 Galíndez vigila a Castro (364)

- 1956 (febrero) Presenta su tesis sobre Trujillo en la Universidad de Columbia (28)

- 1956 (7 de marzo) Último informe de Galíndez (364)

- 1956 (12 de marzo) Es secuestrado (12)

- 1956 (31 de mayo) Balaguer escribe en El caribe que "Galíndez era personalmente un bandido y políticamente un comunista" (275)

- 1956 (6 de junio) Recibe in absentia el doctorado (204)

- 1956 (7 de septiembre) El Departamento Jurídico del Comité Anticomunista asegura que Galíndez fue comunista y criminal (202)

- 1956 (finales) Balaguer crítica al New York Times por preocuparse de Galíndez (275)

- 1957 (3 de febrero) Manuel Ferrandis concluye que unos papeles de De la Maza tienen la misma letra que una carta de suicidio (207)

- 1957 (8 de febrero) Se ordena la autopsia de De la Maza, que determina suicidio (209)

- 1957 (11 de febrero) Time identifica al Cojo como Francisco Martínez Jara, implicado en la desaparición de Galíndez (210)

- 1957 (21 de febrero) Rúa acepta como verdadera la carta de suicidio de De la Maza, su yerno (213)

- 1957 (13 y 14 de abril) El caribe publica la reaparición de Galíndez en México (210)

- 1957 Radcliffe es llevado a los tribunales por mantener relaciones con una alumna (43) 
- 1957 Antonio Bonet escribe una refutación de La era Trujillo (205)

- 1957 (9 de diciembre) John Frank, ex agente del FBI, es condenado por secuestrar a Galíndez $(57,125)$

- 1959 Radcliffe participa en una manifestación contra el gobierno de Eisehower

- 1960 (4 de mayo) Almoina, autor de Una satrapía en el Caribe, es asesinado (337)

- 1960-1968 Balaguer borra las pruebas del caso Galíndez de este periodo (340)

- 1961 (comienzos de junio) Trujillo es asesinado (55)

- 1961 Termina la carrera política de Charles O. Porter (126)

- 1962 (diciembre) Comienza la llegada masiva de cubanos a Miami (369)

- 1967 Se deja entrever que Espaillat fue asesinado (204)

- 1973 (30 de agosto) El asistente del fiscal de la Corte de distrito de la testamentaría de Manhattan da por muerto a Galíndez (127)

El fantasma de Galíndez regresa

- 1982 Norman Radcliffe pasa de enseñar en la universidad de Nueva York a Yale (39)

- 1983 (marzo) Muriel Colbert recibe la beca Holyoke (40)

- 1984 Muriel Colbert se separa de su novio chileno y se va a Madrid (40)

- 1984 El Departamento de Estado empieza a seguir los pasos a Muriel Colbert

- 1986 (abril) La beca de Muriel Colbert es prorrogada (40) 
- 1988 Presente de la narración (57). Robert Robards, agente de los Estados Unidos, dice que, si viviera, Galíndez tendría setenta y tres años. Como nació en mil novecientos quince, la acción empieza en mil novecientos ochenta y ocho

\section{Anexo 2}

Orígenes del conflicto

\begin{tabular}{|l|l|l|l|}
\hline $\begin{array}{l}1936- \\
1939\end{array}$ & $\begin{array}{l}\text { España } \\
\text { Galíndez lucha en } \\
\text { el bando republi- } \\
\text { cano en la Guerra } \\
\text { Civil }\end{array}$ & República Dominicana & Estados Unidos \\
\hline 1939 & Exilio español & $\begin{array}{l}\text { Galíndez llega a Rep. } \\
\text { Dominicana }\end{array}$ & \\
\hline 1941 & $\begin{array}{l}\text { Galíndez propone a Martínez Ubago como } \\
\text { delegado vasco en la República Domini- } \\
\text { cana }\end{array}$ & $\begin{array}{l}\text { Galíndez comienza } \\
\text { a pasar informa- } \\
\text { ción a la embajada } \\
\text { de EEUU }\end{array}$ \\
\hline 1945 & & $\begin{array}{l}\text { Galíndez apoya la la } \\
\text { huelga }\end{array}$ & $\begin{array}{l}\text { Galíndez es agente } \\
\text { fijo del FBI }\end{array}$ \\
\hline 1946 & Huelga & $\begin{array}{l}\text { Galíndez se } \\
\text { traslada a NY }\end{array}$ \\
\hline
\end{tabular}

La desaparición de Galíndez

\begin{tabular}{|c|c|c|c|}
\hline $\begin{array}{l}1953- \\
1954\end{array}$ & $\begin{array}{l}\text { Galíndez publica un } \\
\text { artículo sobre el } \\
\text { vasquismo }\end{array}$ & $\begin{array}{l}\text { Trujillo condena a } \\
\text { muerte a Galíndez }\end{array}$ & \\
\hline \multirow[t]{3}{*}{1956} & & \multicolumn{2}{|c|}{ Galíndez presenta La era Trujillo } \\
\hline & & \multicolumn{2}{|c|}{ Galíndez es secuestrado } \\
\hline & & $\begin{array}{ll}\text { Balaguer llama a } & a \\
\text { Galíndez bandido } & y \\
\text { comunista } & \end{array}$ & $\begin{array}{l}\text { El Departamento } \\
\text { Jurídico del Co- } \\
\text { mité Anticomu- } \\
\text { nista llama a } \\
\text { Galíndez comu- } \\
\text { nista y criminal }\end{array}$ \\
\hline
\end{tabular}




\begin{tabular}{|l|l|l|l|}
\hline 1957 & $\begin{array}{l}\text { El gobierno defiende } \\
\text { que De la Maza se } \\
\text { suicidó }\end{array}$ & $\begin{array}{l}\text { Time identifica al } \\
\text { Cojo como Fran- } \\
\text { cisco Martínez Jara }\end{array}$ \\
\cline { 2 - 4 } & $\begin{array}{l}\text { El caribe publica la } \\
\text { reaparición de } \\
\text { Galíndez en México }\end{array}$ \\
\cline { 2 - 4 } & $\begin{array}{l}\text { Antonio Bonet escribe } \\
\text { una refutación de La era } \\
\text { Trujillo }\end{array}$ \\
\hline $1960-$ & $\begin{array}{l}\text { John Frank es condenado por secuestrar a } \\
\text { Galíndez }\end{array}$ \\
\cline { 2 - 4 } & $\begin{array}{l}\text { Almoina es asesina- } \\
\text { do }\end{array}$ & \\
\cline { 2 - 4 } & $\begin{array}{l}\text { Trujillo es asesinado } \\
\text { nalaguer borra las }\end{array}$ & $\begin{array}{l}\text { Termina la carrera } \\
\text { política de Charles } \\
\text { O. Porter }\end{array}$ \\
\hline & $\begin{array}{l}\text { Inmigración } \\
\text { masiva de cuba- } \\
\text { nos a Miami }\end{array}$ \\
\hline
\end{tabular}

El fantasma de Galíndez regresa

\begin{tabular}{|c|c|c|c|}
\hline 1984 & $\begin{array}{lll}\text { Muriel } & \text { viene } & \text { a } \\
\text { España } & & \end{array}$ & & $\begin{array}{l}\text { El Departamento } \\
\text { de Estado sigue a } \\
\text { Muriel }\end{array}$ \\
\hline \multirow[t]{3}{*}{1988} & $\begin{array}{ll}\text { Muriel } & \text { visita } \\
\text { Amurrio } & \\
\end{array}$ & & \\
\hline & & $\begin{array}{ll}\text { Muriel visita } & \text { Santo } \\
\text { Domingo } & \end{array}$ & \\
\hline & & & $\begin{array}{l}\text { Muriel se entrevi- } \\
\text { sta en Miami y es } \\
\text { secuestrada }\end{array}$ \\
\hline
\end{tabular}




\section{Bibliografía}

Balibrea, Mari Paz. En la tierra baldía. Manuel Vázquez Montalbán y la izquierda española en la modernidad. Barcelona: El Viejo Topo, 1999. Impreso.

Bamberg, Michael. "Why Narrative". Narrative inquiry, 22(1), (2012): 202-210. Impreso.

Benson, Ken. Experimentalismo frente a narratividad. Actas XI de la Asociación Internacional de Hispanistas (1992): 223-238. Impreso.

Bértolo Cadenas, Constantino. "La verosimilitud literaria". Quimera (1991): 61-72. Impreso.

Bodenmüller, Thomas. "Galíndez» o las posibilidades de la novela histórica moderna". Hispanorama: Zeitschrift des Deutschen Spanischlehrerverbandes 90 (2000, noviembre): 75-79. Impreso.

Bonilla-Atiles, José Antonio. Carta Pública, 21 de febrero de 1946. En Discursos y conferencias enjuiciando la política del presidente Trujillo. Ciudad Trujillo: Veritas, 1946. Impreso.

Champeau, Geneviève, Carcelén, Jean-François, Tyras, Georges y Valls, Fernando (coord.). Nuevos derroteros de la narrativa española actual veinte años de creación. Zaragoza: Prensas universitarias de Zaragoza: 2011. Impreso.

Colmeiro, José F. "La verdad sobre el caso Galíndez o la reescritura de la historia". Asociación Internacional de Hispanistas (1992): 211221. Impreso.

García Posada, Miguel. "Galíndez". ABC literario (1990, 5 de mayo). Impreso.

Habermas, Jurgen. El discurso filosófico de la modernidad (doce lecciones). Madrid: Taurus, 1989. Impreso.

Kanno, Yatsuko and Stuart, Christian. "Learning to Become a Second Language Teacher: Identities-in-Practice". Modern Language Journal 95, 2 (2011): 236-252. Impreso.

Magariños Fidalgo, Montserrat. El poder y el individuo en Galíndez. Obtenido el 3 de octubre de 2018. Sitio web: https://bonoc.files.wordpress.com/2008/05/el-poder-y-el-individuoen-galindez.pdf

Navarro, J. J. "Investigación”. El país (1990, 15 de abril). Impreso.

Navarro, María José. "Galíndez: juego literario, reflexión política". Reseña de Literatura, Arte y Espectáculos 210 (1990, octubre): 40. Impreso 
Pittarello, Elide. "Más sobre historia y ficción. Galíndez de Manuel Vázquez Montalbán". Actas XIII de la Asociación Internacional de Hispanistas. Tomo II (1998): 742-748. Impreso.

Roca Sierra, Marcos. La construcción del sujeto en la narrativa española actual. Madrid: Fundación Universitaria Española, 2003. Impreso.

Sevilla-Vallejo, Santiago. Cómo escribir ficciones según Gonzalo Torrente Ballester, Saarbrücken: Editorial Académica Española, 2017a. Impreso.

---. "Why should teachers tell stories at class? Narration for Educative and Identity Purposes". En Javier F. García, Teresa de León y Eduardo Orozco (eds.). Las tecnologías de la información y comunicación para la innovación y el desarrollo. Madrid: Alexandria Library, (2017b): 287-308. Impreso.

Tyras, Georges. Conversaciones con Manuel Vázquez Montalbán. Granada: Zoela ediciones, 2003. Impreso.

Valls, Fernando. La realidad inventada. Barcelona: Crítica, 2003. Impreso.

Vázquez Montalbán, Manuel. Galíndez. Barcelona: Diario Público, 1990. Impreso.

---. Panfleto desde el planeta de los simios. Barcelona: Crítica, 1995. Impreso. 